\title{
INTERNATIONAL TEA MARKETING AND NEED FOR REVIVING SRI LANKAN TEA INDUSTRY
}

\author{
Mohamed Ismail Mujahid Hilal \\ Senior Lecturer, Faculty of Management \& Commerce \\ South Eastern University of Sri Lanka \\ Kaldeen Mohamed Mubarak \\ Senior Lecturer, Faculty of Management \& Commerce \\ South Eastern University of Sri Lanka
}

\begin{abstract}
The objective of this paper is to analyze present trend of Sri Lankan tea industry and to identify problems in international marketing of tea. Qualitative methodology was adopted in this study. Checklist was prepared and researchers interviewed twenty six experts from tea exporting and marketing companies in Sri Lanka. Any strategy that will enhance the competitiveness in terms of sustaining competitive advantage globally is held up by high cost of production. Therefore, it is recommended that Sri Lanka needs to follow one of the best international entry modes to market tea internationally by having international organizations in tea marketing and exporting companies. This will help the industry improve the profitability and thus, protect people working in the plantation and Sri Lanka will get economic benefits. It is favorable for Sri Lanka having properly designed product, promotion, pricing and distribution strategies in accordance with the needs of international tea market are imperative for Sri Lankan tea industry to face the marketing challenges prevailing in the international tea market, which will assist Sri Lankan tea industry in competing intensively with other tea exporting or re exporting countries. Sri Lankan government may also extend massive support to the industry to convert export companies into international marketing oriented firms.
\end{abstract}

Keywords: International marketing, tea, Sri Lanka, exports

\section{Introduction and Significant of the Study}

The business environment is said to be more competitive with dynamic changes of customers in their preferences. At this juncture, export performances of countries are also seriously considered in order to fulfill the different needs of customers in all businesses in all countries (Eusebio et al., 2007). International tea market, which comprises Sri Lanka, Kenya, China, India, Malawi, and Vietnam as major producers and exporters, are more dynamic and competitive in the vigorous international business environment. In the global tea market, although Sri Lanka is having considerable amount of income and employment generation from the tea industry, Sri Lankan competitiveness is substantially falling and thereby it is extremely difficult for Sri Lanka to have and maintain competitive advantage. The main reason for not having competitive advantage is lower productivity and high cost of production (Dulekha, 2008). In fact, in 1999, Sri Lankan tea had 21 percent international market share which was only 18.18 percent in 2008 but Kenya was having 23.34 percent export share internationally in the same year.

While considering the present situation of the tea industry of Sri Lanka, a strategy that will enhance the competitiveness in terms of sustaining competitive advantage globally is held up by high cost of production. Hence, the alternative approach is to convert exports into fully international marketing. Thus, the objective 
of this paper is to analyze present trend of Sri Lankan tea industry and to identify problems in international marketing of tea that should be addressed with proper planning. There for this paper has been prepared in the following line. Firstly the introduction and significance of the study is precisely given. Secondly, an analysis is done with secondary data from various sources on international tea market explaining the position of Sri Lankan tea in the international market. Thirdly, review of related literature is given which explain how the industry competitiveness is declining in the international tea market. Fourthly, research methodology adopted for this study is elaborated. Qualitative data analysis and findings are given fifthly. The conclusions and recommendations are provided at the end of this paper.

\section{Analysis of Sri Lankan Tea Industry and International Market}

Sri Lanka has secured an eminent place in the tea production and export in the world among the tea producing countries. Presently, Sri Lanka is the second world exporter of tea and maintaining distinguished image among the country markets. Sri Lanka exports 94 percent of it tea production to the world markets. Further, it generates more than one million employments in the country directly and indirectly. The tea industry contributes 15 percent to the foreign exchange earning of the country. Although it is having considerable foreign exchange earnings, the country will have economic benefits when the industry is maintaining sustainable competitive advantage over other tea producing and exporting countries.

China and India are the major countries with the largest tea production when compare with other producing nations. These two countries are major producers and consumers of tea in the world.

Sri Lanka is the fourth largest tea producing country in the world. Kenya is the third largest producer in the world and China and India are the first and the second largest tea producers respectively. When observing Turkey, Indonesia and Vietnam, their production of tea is in the increasing trend in the global market. This indicates that these countries are emerging as competitors to the major producers in the international market.

\section{Sri Lanka's Tea Export Markets}

Sri Lanka is exporting tea to various countries in the world. While major importing countries are consuming Sri Lankan tea and some of major countries that import Sri Lankan tea re export to various countries as value added tea for which the demand is growing to a large extent internationally. Some of Sri Lanka's major markets include Russia, United Arabic Emirates, Syria, Turkey and CIS. Major re exporting countries are United Kingdom, USA and Germany.

According to the statistical database of the Food and Agricultural Organization, major country markets for tea in the international market are the Russian Federation, United Kingdom and United Arab Emirates and USA in the world. Sri Lanka is exporting to Russian Federation only 26.8 percent (Calculated based on the Sri Lanka Tea Board Statistics) of total tea exported to that country and other rest of the tea is being exported other major producers specially by Kenya. United Kingdom is also one of the major tea consuming countries in the world. This country's tea need mostly fulfilled by Kenya. This unpleasant situation also stresses the urgent need for competitive strategy to uplift the tea industry of Sri Lanka.

When Pakistan is taken into consideration, it is one of the major tea consuming countries in the world and it is one of lucrative markets for Sri Lankan tea. In fact, the market size of the Pakistan tea is $160-170$ million Kilogram annually. Tea import of Pakistan is also drastically increasing annually. Interesting point is that the import from Sri Lanka is falling from 3640 MT to 702 MT in 2007 with market share of merely 0.66 percent (SLTB, 2007). In 
contrast, the Kenya's market share in Pakistan was increasing from 53.93 percent to 65.85 percent in 2007 (SLTB, 2007). This shows that Sri Lanka has lost its market in Pakistan as well. It is due to the fact that the escalated price of Sri Lankan tea derived from increased cost of production.

Sri Lanka is exporting most of the tea as bulk and not in the form of value addition. Therefore, it is extremely difficult for Sri Lankan tea industry to compete with other major tea exporters in the world. For instant, Kenya, India, China, Vietnam, Malawi and other tea producing countries are exporting bulk as well as value added tea at a lower prices comparing with Sri Lanka. Hence, the competition among exporting countries is taking place on price not on quality. This is one of the foremost reasons of declining in competitiveness of Sri Lankan tea in the global market.

Having a look at the export trend of major tea exporters enables us to gain insights into the international tea market and competition. Sri Lanka is facing rigorous competition from Kenya, Vietnam and Indonesia because Kenya captured most of the market since 2004 to date due to the popularity of the CTC (cut, tear and curl) tea it produces and has been capturing many markets due to the higher demand for CTC tea at low price. Sri Lanka is producing orthodox tea which is higher price when compare with other orthodox tea producers such as Vietnam and Indonesia of which the price is cheaper than Sri Lankan orthodox tea (Dulekha, 2008). Although the competitive activities of Vietnam and Indonesia are insignificant for Sri Lankan tea industry, they are emerging as competitors for Sri Lankan tea industry in the international market.

According to Food and Agricultural Organization's statistics, tea export of Sri Lanka has been falling and Kenya is surpassing Sri Lanka after 2004. Further it is noted that Malawi, Argentina, Vietnam and Tanzania are developing as emerging competitors for Sri
Lankan tea. Probably, these countries will compete with Sri Lanka effectively and efficiently in future.

\section{Re-Exports of Tea}

Sri Lankan tea industry is facing competition from countries which are re exporting to major country markets. These countries are United Kingdom, German, Russian Federation, United States of America, France, Netherlands and Belgium. These countries are importing tea in bulk form from major producer countries and converting it as value added tea which has increasing demand internationally and it gives healthy profits than the tea growing nations. All most all the nations are exporting tea as primary commodity to these re exporting countries. The major pitfall of this operation is that the country which re exports tea as value added tea earns large margins than tea producing countries (Fonseka, 1997).

United Kingdom is one of the major tea importer in the world with per capita consumption of tea is $2.17 \mathrm{Kg}$ per year. Further, tea is one of the leading beverages with 35 percent share in the beverage market. Sri Lanka is losing this huge market for many years and most of the tea needs are fulfilled by Kenya and the United Kingdom exports 20 percent of tea to the European Union, Canada, USA and Japan (SLTB, 2007).

The problem for Sri Lanka in re exporting of tea by other countries is that re exporting countries are exporting the value added tea under their own brand in which the origin of tea is not mentioned. Likewise, even in Sri Lanka, the multinational companies are exporting packeted tea and instant tea or in bulk under the distributors' brand name, which is not giving any competitive advantage for Sri Lankan tea.

\section{Increasing Cost of Production of Sri Lankan Tea}

The unit value (\$/Tonne) of exported tea from Sri Lanka is higher than the other countries' unit value. It is noted that according to the FAO 
statistics, the unit value of exported tea from Kenya was US \$ / Tone 1867 meanwhile the unit value of the Sri Lankan tea was 2865 US \$/ Tone. This trend of unit value indicates that the competitiveness of Sri Lankan Tea is declining during the past many years. The main reason for the decline in competitiveness is price competition.

In addition, we can see the increased cost of production of Sri Lankan tea. The following table gives the unit cost of production per kilogram of made tea produced in Sri Lanka.

\begin{tabular}{|c|c|c|c|c|c|c|c|c|c|c|}
\hline Year & 1998 & 1999 & 2000 & 2001 & 2002 & 2003 & 2004 & 2005 & 2006 & 2007 \\
\hline $\begin{array}{c}\text { Cost } \\
\text { (SL Rs/Kg) }\end{array}$ & 100.82 & 105.88 & 113.39 & 121.97 & 126.72 & 133.09 & 149.13 & 161.98 & 210.75 & 231.49 \\
Source: Agriculture and Environment Statistics Division, \\
Department of Census and Statistics, Sri Lanka
\end{tabular}
S

It is observed that the cost per kilogram of tea in Sri Lanka drastically increased to SLR 231.49 per $\mathrm{Kg}$. This was also one of the reasons for increasing the unit value of the exported tea from Sri Lanka.

\section{Review of Literature}

\section{Competitive Environment of Sri Lankan Tea Industry}

The industry environment comprises the economic factors such as customers, competitors, suppliers, buyers, and potential substitutes which are directly relevant to a specific industry (Pitts and Lei, 2007). In order to analyze the industrial environment Porter developed a model called Five Forces Model (Figure 1). The five forces in the competitive environment have impact on the industry attractiveness which determines the potential profitability of the industry.

\section{Industry competitors}

Thirty four countries are producing tea in the world in which Sri Lanka, Kenya, India, Chain, Indonesia and Vietnam are major producers in the world. The tea industry is experiencing harsh competition in which Kenya, Sri Lanka, India, China and Indonesia are the major rivals in the market. Due to the lower cost producer, the market leader Kenya is having high growth rate comparing with Sri Lanka. Kenya had 25.64 percent growth in production of tea form 1998 to 2007 but comparatively Sri Lanka had only 8.98 percent growth in production in the same period. Further, these six countries represent 84.21 percent (Calculated based on the ITC Report) of total tea export of the world. The differentiation strategy is not pursued increasingly in Sri Lanka. It is because of the fact that 60 percent of tea exported from Sri Lanka is in the form of bulk another 40 percent are exported as tea packets and tea bags to various countries under distributors label. Since the demand for value added tea is in increasing trend, the value added tea exported from Sri Lanka is not in significant quantity to accomplish the requirements of the foreign markets. Another important point is to stress here is that considerable quantity of tea is being exported to international tea processing firms to add value and to be sold by them under their own brand. Exit barriers arise in the industry due to the huge investment in machinery and other assets which cannot be reused if the industry is shutdown (Fonseka, 1997). As a consequence, exit barriers are also likely to be discouraged.

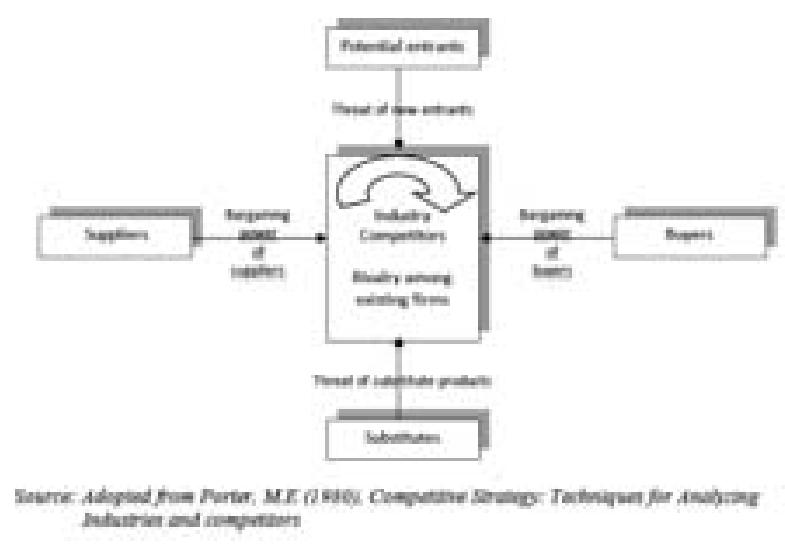

\section{Figure 1: Porter's five forces model of} industry attractiveness

\section{Threat of new entrance}

Although some new countries entered into the tea industry in the past decades, some of the major producing countries are manufacturing tea 
at lower cost when compared to Sri Lanka. This causes threats to the new entrance. In addition to that, some of the eminent brands in the world tea market bring premium prices and thereby the firm earns larger margins. In fact multinational companies are having well known brand with more than hundred years of survival in the market. For example, Ty-phoo Tea Ltd. is marketing tea under the different brand names such as Ridgways, Lift, Glengettie, Fresh Brew, Melrose's for consumers with varied tastes and different requirements. Similarly, Lipton, Tetley and PG Tips are also marketing value added tea at premium prices. Further, the agro climatic conditions and the duration of yield are also encouraging barriers to new entrance. Thus, it could be stated that the threat of new entrance is positive in the tea industry.

\section{Threat of substitutes}

Despite the tea is the cheapest beverage next to water, tea has enormous substitutes in the beverage market. These are milk, carbonated soft drink, fruit juice, coffee, alcohol and other drink. Even if the demand for tea is increasing in the international market due to the health benefits contained in it, the consumption of soft drinks have not fallen to that extend of significant level. Also most of the young people leisurely want carbonated soft drink not tea. Hence it can be concluded that the threat of substitutes is high.

\section{Power of buyers}

Since the standardized or undifferentiated product is sold at auction, the price is determined at the auction itself as a result of that the bargaining power of buyers has been raised in the tea industry (Ali et al., 1997). Further it has been identified that ultimate consumers need value for money so that most of the developed countries' consumers demand for quality tea from overseas retailers. Then, the overseas retailers will demand premium quality tea for gaining brand loyalty from their customers (Outschoorn, 2000). In this way the buyers exert more influences on the industry.

\section{Power of suppliers}

Suppliers are exerting power on industry and have impact on profitability. It is obvious that tea industry has to depend on many foreign and local suppliers such as companies importing agro chemicals, fertilizers, tea chests and packaging materials which are imported from Singapore, India, Indonesia and Russia and also transport association has leverage on the industry due to the transport form tea factory to Colombo Auction (Fonseka, 1997).

Analysis of competitive forces shows that these five forces are high in the tea industry. This will have impact on the attractiveness and profitability of the industry. Therefore it is essential to formulate strategy for the tea industry to overcome competition in the industry and to gain competitive advantage in the international tea market.

\section{Competitive Advantage for Sri Lankan Tea Industry}

The nature of industrial competition has been changed by global competiveness, reduced product life cycle, growing technological advancements and changing customer requirements so that the price (cost) will not be sole factor for competitive advantage (Beal and Lockamy, 1999). Competitive advantage is vital for Sri Lankan tea industry because it is required for Sri Lankan tea industry to formulate and implement strategy that gives sustainable competitive advantage. Sri Lankan tea industry should have distinctive competence which enables the industry to differentiate itself from competitors and create competitive advantage. These distinctive competences include innovative product design, low cost manufacturing, superior quality and superior distribution, which Sri Lanka should have to build up competitive advantage in the tea industry for an extended period (Pitts and Lei, 2007). It has been further accentuated that Sri Lankan tea industry will face uncertainty in future if it has no strategic ideas for developing the basis for competitive 
advantage which is important to boost the performance and to face the increasing competition in the global tea industry (Ariyawardena, 2003).

Considering the situation of Sri Lankan tea industry, achieving sustainable competitive advantage with competitive strategies is extremely difficult. Because the competitive advantage is not a matter of fact to be achieved immediately and it cannot easily be identified by firms. It is a journey for an organization but not a destination and most of the organizations are having problems in finding where the journey is in the competitive environments due to its changing and unpredictable style (Chaharbaghi and Lynch, 1999).

Competitive advantage can be defined as a outperforming of an industry that produce products with giving more value to the customers than competitors (Porter, 1985). Here it has been emphasized that industry's competitiveness in the international market owing to the national condition. It is the diamond of competitive advantage which comprises factor conditions, demand, related and supporting industries, firm strategy, structure and rivalry and externally government influences. When all these national conditions are positively giving strong support for the manufactures, the industry will experience competitive advantage globally. Competitive advantage should be identified and achieved on the basis of attributes which others cannot replicate but it is imitated globally due to the inability of firms to have patent for their innovation (Kanmpully and Duddy, 1999).

The diamond of competitive advantage model can be applied to the Sri Lankan Tea industry to understand the global competitiveness of it. Because the model suggests that nations' basic factors determine the achievement of competitive advantage internationally. In fact the industry is facing problem of higher cost of production when compared with other tea producing nations. The cost of production for one kilogram made tea in Sri Lanka was SLRs 100.82 in 1998 but it was SLRs 231.49 in 2008 (See Table 5) and hence the factor condition is not supportive as Sri Lanka's labour cost is high. Meanwhile, the demand condition for Sri Lankan tea is conducive to the competitive advantage. It is because of the fact that Sri Lanka tea is having higher demand abroad and its quality level is also higher. Firm strategy, structure and rivalry are also deciding factors of competition in view of how the firms are established and managed. In the case of Sri Lankan tea industry, the increased productivity and innovation have to be encouraged to achieve global competitive advantage. In Sri Lanka, the support given by the government is also not enough for the industry. The government should also be able to provide ample and strong support for the industry in order to build up competitive advantage globally. Export promotion programs should be provided by the government to tea producing firms with the view to increase export performance by improved capabilities, resources and strategies which will pave the way for overall competitiveness (Francis et al., 2004).

All businesses are succeeding due to some advantages over their competitors, which mean that they should have competitive advantages. Any firms that have competitive advantage in the industry put forward some strategies such as innovation, improved processes, higher quality, lower cost and marketing for achieving their business objectives (Rijamampiania et al., 2003). Sri Lankan tea industry does not possess innovative ideas to market tea products internationally and it has no lower cost production as well due to the increased cost of factor condition. Therefore Sri Lanka should devise a specific strategy in terms of gaining competitive advantage over other tea producing nations like Kenya.

The industry of Sri Lanka could be innovative in producing and marketing tea products in accordance with the requirements of foreign 
markets, which will enable the industry to gain competitive advantage in global market. It is because of the fact that sustainable world class performance cannot be achieved when there is an imbalance between the firm's competitive strategies and requirements of the market (Beal and Lockamy, 1999). There are five sources of innovation from which competitive advantage could be achieved through. They are the new technologies, the modification of the demand or a new demand, the occurrence of a new segment, the changes in the costs or the availability of means of production and the changes in the regulation (Passemard and Kleiner, 2000).

The tea industry can locate its sources of innovation for competitive advantage in the modification of the demand or a new demand and in the new segment for tea. Because, value added tea is having growing demand in the international tea market. Although Sri Lanka has introduced value added tea to different international markets, the quantity and the extend of value addition is not considered to fulfill the present requirement of the global market. Because the choice of strategy and ability to perform the specific strategy are weakly associated with core resources of value added tea producing firms and thus Sri Lankan tea producing firms have to enhance the core resources to achieve the competitive advantage (Ariyawardana and Bailey, 2002). However, there is a good demand for specialty (White, green and other value added) tea and there is decline in sale of black tea presently and it is further highlighted that the white tea is a new trend in international markets owing to its more health advantages than green tea (Gourmet Retailer, 2005). When the export of tea from Sri Lanka is examined, only small portion of green tea is being exported to major markets. The relationship among the exporters, importers and other members in the supply chain will also create competitive advantage which is extremely difficult to be reproduced by competitors in tea industry (Kasturiratne and Poole, 2006).

\section{Generic Strategies to Build Competitive Advantage}

Despite there are many ways for competitive strategies, Porter has identified three generic strategies which can be used as sources of competitive advantage for Sri Lankan tea industry. This is shown in the Figure 2.

\section{Cost leadership strategy}

Low-cost leadership strategy requires producing tea product at lower cost and prices it at lower level than the competitors' price as a result of which the industry will gain competitive advantage but in the case of Sri Lankan tea industry, achieving lower cost leadership is not possible due to the high cost of production. The reason for the higher cost of production because

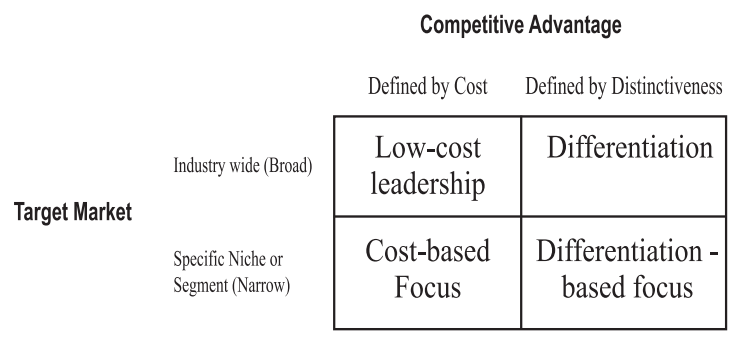

Source: Adopted from porter, M.E. (1998) The competitive advantage: creating and sustaining superior performance with a new introduction

Figure 2: Three generic strategies

of the high wage, lower productivity and lower yields when compare with other major producers (Outschoorn, 2000). Sri Lankan tea industry will be able to convince the competitors not to compete on price if they have the cost leadership strategy. Thus, Kenya and some other major tea producing countries are having lower cost of production and maintaining competitive advantage over Sri Lankan tea industry and capturing the global tea market. To achieve the cost advantages, firms has to put more efforts on controlling production and marketing costs by reducing various costs including $\mathrm{R} \& \mathrm{D}$ and other distribution and promotional costs (Prajogo, 2007). Sri Lankan tea industry is not in a position to bring down the costs incurred for tea products because it is in need of carrying out 
marketing research activities abroad and has to invest on improving the product and promoting them to international arena.

\section{Differentiation strategy}

Differentiation strategy involves giving consumers products with different attributes which differentiate the product from competitors' offerings. This strategy is a source of competitive advantage in the way of delivering distinct products which are attributed by some different features such as quality and innovation, consumers will pay premium prices for the product due to the additional value to customers (Prajogo, 2007). Since Sri Lanka is having higher cost of production, it is better for Sri Lankan tea industry to adopt differentiation strategy for gaining differential advantage. Also the quality and other features of Ceylon tea are encouraging this type of strategy. In Sri Lanka, tea is manufactured in six different agro climatic regions with varied specialty tea suitable to different consumer tastes and lifestyle (Dulekha, 2008). This can also be used as one of the differentiation strategies on which the competitive advantage is based. Despite there are many sources of competitive advantages based on the differentiation, strategies based on high quality will definitely increase the market share Pitts and Lei, 2007).

\section{Focus strategies}

This is the third generic strategy. It targets narrow segment or regional markets for a product. Due to this focus strategy firm can attract new customers or attract repeat purchases. Firms can pursue this strategy either adopting a differentiation - based focus or adopting cost based focus. As far as Sri Lanka is concerned, the cost based focus strategy cannot be adopted due to the increasing cost of production but it is possible to take up differentiation based focus. For this reason, Sri Lanka tea industry can follow differentiation based focus strategy by identifying niche markets for specialty tea.
Sri Lanka can maintain competitive advantage only when they are having value added tea products with differentiation strategy. If not, it is extremely difficult for the industry to sustain competitive advantage over other competitors like Kenya, India, China and Indonesia.

\section{Research Problem}

Sri Lanka is the fourth largest producer among the major producers namely China, India, Kenya, Indonesia, Vietnam and Malawi. The Kenya is the market leader in the international tea market and it has been capturing most of the market since 2004. The most important problem faced by Sri Lankan tea industry is that bulk tea exported to various tea processing multinational companies in the world and it is processed as value added tea and re exported to major markets under the multinational companies' brand. Consequently, Sri Lanka is losing globally its image as Ceylon tea. Although researchers Dulekha (2008), Fonseka (1997), Ariyawardena (2003) Outschoorn (2000) suggested that differentiation strategy is an important strategy for the industry. According to the literature, high cost of production and unfavorable factor condition obstructed differentiation strategy and these led the industry to less competitiveness in the global market. Hence, Sri Lankan tea industry may attempt to engage in international marketing rather than putting efforts on exporting tea to the world markets. It is also pertinent to point out that re exporting countries are exporting the value added tea under their own brand in which the origin of tea is not mentioned. Likewise, even in Sri Lanka, the multinational companies are exporting packeted tea and instant tea or in bulk under the distributors' brand name, which is not giving any competitive advantage for Sri Lankan tea. It is, therefore, healthier to understand and list out the problems faced by the Sri Lankan tea industry with regard to international marketing of tea. This will help formulate international marketing strategies for Sri Lankan tea in the international market. 


\section{Research Methodology}

Qualitative methodology was adopted for this research. Primary and secondary data were used for this study. Secondary data were obtained from Sri Lanka Tea Board Annual Reports, Food and Agricultural Organization's database and International Tea Committee Annual Reports. A checklist was prepared and researcher met twenty six experts on tea exporting and marketing from twenty six companies in Sri Lanka. Due to executives' time constraints, researchers used telephone interviews as well. Since these experts are associated with many activities in their business, appointments were fixed. However, it took three months to complete the interviews with experts from these companies. Each interview took one and half hour to complete the interrogation duly.

Thematic analysis technique was used in this study. Qualitative information collected from the interview was recorded and transcribed by researchers with a view to familiarize with dataset enabling to generate initial codes for themes systematically. Then, similar codes which represent international marketing related problems into potential themes which production related problems, issues in export of Sri Lanka, international tea market and value added tea and marketing. These themes were used in the analysis.

\section{Data Analysis and Finding}

\section{Production Related Problems}

Despite the fact that tea production is increasing in the country every year by 8 per cent to 10 per cent, it is stagnant because it has increased from 300 million kilograms to 310 million kilograms.

Interviews with exporters reveal that major problem in the production of tea is increasing cost of production. It was found that reasons for increased cost of production are higher wage of labors, increased price of fuel, increased electricity charges and high price of fertilizers. It is also noted that 70 per cent of the total cost of production is represented by labour cost. Other costs such as electricity also involved in the increased cost of production.

Though Sri Lankan government provides fertilizer on subsidy, it is not filling the requirements of tea planters. This affects the production of tea and it causes inferior quality of tea during production.

Another important issue is unfavorable climatic condition that prevails in the tea plantation areas is badly affecting the tea production and gets high moisture and high impurity which affect quality adversely. As a result, tea plantation companies are getting low yield compared to the favorable climatic periods. This also impact on the quality of tea produced and therefore, constant maintenance of quality of tea is very difficult for companies. In addition, interviewees disclosed that adverse whether condition and very old bushes in plantation areas also rooted low productivity.

Interviews with experts revealed that a number one orthodox tea producer in the world is Sri Lankan tea industry and many major markets are falling in favour of Sri Lanka orthodox tea. Further, Sri Lankan tea is produced under different climatic condition and under different elevations. Hence, the quality differs according to the elevation such as high grown, lower grown and medium grown. This is an advantage for Sri Lankan tea for having competitive advantage in the international market. The very best tea that Sri Lanka produces is high grown tea which has a beautiful golden liquor and intense powerful flavour. Another different quality tea is medium grown tea which better in flavour, aroma and colour. Another different quality tea is that low grown tea which is known as leafy grade tea. This is long leafed tea gives a slightly sweet aroma and a gentle smooth taste and usually used in blending. 


\section{Problems in Exports of Sri Lankan Tea}

Sri Lanka has already lost its major markets such as United Kingdom and Pakistan due to high cost of production. Interview with exporters emphasized that these two major country markets are no longer international market for Sri Lankan tea. It was also revealed that high cost of production and low productivity lead to high price and hence, bulk tea prices reached to the maximum. While Sri Lankan companies which export bulk tea are straggling in finding investment to export value added tea products to the world, the CESS which is levied by the government of Sri Lanka in order to discourage the bulk tea exports and encourage the value added tea exports from Sri Lanka. This also put additional burdens on the companies.

It is explicable from the interviews with exporters that iron filing is affecting Sri Lankan bulk tea exports. International markets are reluctant to accept tea that contained iron filing. The iron filing should not exceed the prescribed limit. Sri Lankan tea contains iron filing above the limits. Hence, it is also a biggest problem for Sri Lankan tea and it affects the export of tea.

Competition on price is another reason that affects the tea exports. Sri Lanka has high cost of production and thus, it is compulsory for the exporters to price the tea at high level. As a result, Sri Lankan tea has been pushed to the price competition. Other tea producers such as Kenya, Vietnam and other cheaper tea producing nations are utilizing this as an opportunity and export tea to country markets at low price.

Interviewees revealed that reasons for decreasing demand for the Sri Lankan tea in the world market is sky rocketing cost of production in Sri Lanka and increased production of Kenya with its virgin soil. It was exposed that Sri Lankan tea had increasing demand before 1998 and then gradually decreased due to the inability of paying high price of Sri Lankan tea and it had gone up from US \$ 2.5 to US \$ 3.8.
Sri Lanka is focusing on orthodox tea which accounted for almost 95 per cent of its tea production. Sri Lanka is principally being an exporter of bulk tea. However, there has been a gradual shift in consumption patterns with several countries switching to the use of more convenient form of the beverages such as tea bags. Hence, Sri Lanka has problems in marketing tea in the global market.

According to interviews with experts, the consumer preferences are continuously changing in the international tea markets. Now consumers want convenient products that fulfill the tea requirements easily and these consumers want more health benefits from the tea products. Hence consumers are moving from traditional tea brew to tea bags and to instant tea. Since Sri Lanka is having the highest cost of production in the tea industry, Sri Lankan tea is sold at expensive prices compared to the other origin tea. As a result the price competition arises between tea producing nations. Tea producing nations such as Vietnam, Indonesia and Kenya have lower cost of production and thereby they price their tea products at lower price.

\section{International Tea Market}

As far as method of production is concerned, the orthodox method of production is good for differentiating Sri Lankan tea from other origin's tea. Although we are able to differentiate our tea from the other CTC tea, the CTC tea is more germane to the tea bag and it has more demand globally.

There are problems related to protectionism as well. This problem is mostly for value added tea. For example Russian Federation levies more tax for value added tea. Local blending and processing of tea in tea consuming countries are also problem for Sri Lankan tea in the international market. Most of the major country markets import tea from various origins and blend it in accordance with the requirements of local and global consumers. The problem is here 
that they blend it not under the Sri Lankan brand but under the private brands. Thus, Sri Lankan tea's identification and its image in the global market are being vanished. This marketing strategy of other countries attributes negative effects but the blending countries generate more employments in the country. This is the reason why Russian Federation buys 20 per cent of the Sri Lankan tea production and the United Arabic Emirates buy 28 million kilograms of tea out of 330 milling kilograms of tea production in Sri Lanka. On the other side this local blending activities also impact on the tea market and it become competition among the tea producers and value added tea producing global companies.

Experts reiterate that the consumer preferences changing all over the world. Changing consumer preferences in the sense, the younger generation wants specialty tea like, green, white tea etc. In most of the major markets, the value added tea has more demand. For instant, the tea bag demand is growing rapidly in the city areas of any country markets. The iced tea has more demand in the United States.

Interviews with experts revealed that the bulk tea exports to Commonwealth Independent States (CIS), Australia and Russian Federation are increasing. The specific reason for the increase of bulk tea export from Sri Lanka to CIS countries is that the bulk tea is blended locally in the country markets in line with the requirement of both domestic and international consumers and be re exported to major country markets. Through this blending process the CIS countries generate more employment domestically. It is also stated that tea exports to traditional markets such as European countries, Middle East and Pakistan have substantially declined due to the cheaper tea from other tea producing nations. These markets have been captured by the Kenya but still Russian Federation, CIS countries and Egypt and Libya are traditional markets for Sri Lankan tea.

Interviewees signified with regard to Pakistan market which is one of the major markets for bulk tea in the world. Consumers in Pakistan are not concerned about the quality of tea. Since the price of the Sri Lankan tea is higher compared to the other origins' tea and Pakistan needs CTC tea which Sri Lanka produced only 15 per cent of total production, Pakistan is no more a major market for Sri Lanka. Contrarily, Russian Federation is more prone to quality of tea, Sri Lankan bulk tea has more demand in this market. Iran is also one of the major markets for bulk tea but they are looking at the packing quality of tea. Hence they import more bulk tea and pack it in the country itself in accordance with their quality standards. Dubai is also a major market for bulk tea. The import lager quantity of bulk tea and blend it at cheaper cost. It is pertinent to note here that all these traditional markets require high quality tea. However, Sri Lanka is struggling in constant maintaining high quality of tea due to unavoidable climatic problems and high cost of production.

With regard to the marketing of tea, interviews with experts revealed that around 70 per cent of Sri Lankan tea export companies are mostly engaged in direct exports. In other words, the marketing channels are through importers who are responsible for the distribution of tea in the country markets and rest is exporting through their agents.

\section{Value added Tea and Marketing}

Sri Lankan tea industry is producing value added tea for international market. Although Russia, UK, USA and UAE are the major market for value added tea products, Sri Lanka does not tap into these major markets. Instead, Sri Lankan tea industry targets Russia, Syria, and Jordan as its major destination for tea bags. Interviews with exporters revealed that many non tea producing countries are also manufacturing tea bags and re export to various destinations, which a barrier for Sri Lankan tea bag producers. It is understandable from the expert interviews that Kenya is also using its 95 per cent of its tea for the production of teabags. 
Sri Lankan value added tea marketers face severe competition from the international manufacturers of value added tea like Unilever and Tata Global Beverages. It is also very difficult to promote Sri Lankan value added tea in the international market due to lack of promotional budget. Sri Lankan tea bags are exported only 7-10 million kilograms of which very few branded tea but Uniliver alone markets 100 million kilograms of Lipton tea bags globally.

It was revealed that the branding plays major role in marketing the Lipton and their investment. Unilever is marketing Lipton tea bags globally with huge promotional expenditures. Sri Lanka has taken insignificant efforts to market teabags under its own brand. Sri Lanka is facing problems in branding tea products. Unlike Lipton, Sri Lankan companies are facing problems in branding tea bags for European countries. The brand names which Sri Lankan companies own do not give proper identification and image for the Sri Lankan tea bags except few companies like Dilmah.

Tea bags are being promoted by advertisement, hording and billboards in many country markets. Sri Lankan companies bear 50 per cent of total cost and the rest will be borne by importing agent in some country markets. Further, Sri Lankan tea bags are promoted at supermarket chains in the country markets for which Sri Lankan companies wanted to pay US $\$ 40,000$. This is pricey for Sri Lankan companies and this promotional aspect is applicable in most of the European country markets. But this cannot be done by the Sri Lankan companies due to the lack of promotional budget.

Sri Lankan marketers are selling one brands in one market or different brands in the markets. It is depending on the consumer requirements i.e. taste and use of the tea. Sri Lankan tea bags producers sell different brands in different market globally. Akbar brands are marketed worldwide especially in Europe and Commonwealth Independent States. Akbar brands are offering a comprehensive range of tea products including tea bag as major product. Further, the Akbar carries lion logo endorsed on the products which used for identification of origin of tea.

According to the expert interviews major markets for instant tea are United Kingdom, German, Canada and USA. Japan and Maldives are also becoming one of the major country markets for instant tea. Although Sri Lanka is one of the major tea producing countries in the world, Sri Lanka faces with technological problem coupled with research and development involved in instant tea production, for which substantial investment is required. Thus, insignificant quantity of instant tea is being exported from Sri Lanka and therefore, experts are of view that there is no market for Sri Lankan instant tea. Therefore, multinational companies have intensely invested in manufacturing instant tea and captured the instant tea markets globally.

\section{Conclusions and Recommendations}

Sri Lanka is one of major tea producers in the world. Despite the fact that Sri Lankan tea industry has different quality of tea with different tasty and aroma in accordance with agro climatic conditions prevail in the country, Sri Lankan companies are unable to market it with proper strategies through which competitive advantage could be achieved. Global consumer preferences are also changing. Thus, more convenient tea product has growing demand in the global market. Sri Lankan tea has been trapped in price competition as a consequence of high cost of production. Although Sri Lankan tea industry has best source of competitive advantage, it finds difficulties in capitalizing the advantage globally owing to the helplessness of engaging in international marketing activities. It is pertinent to note that 70 percent of companies in Sri Lankan tea industry are engaged in direct exporting of bulk tea and value added tea for distributors' brand. Hence, it is inferred that the economic benefits of tea plantations and 
production hardly reach people who utterly depend on the tea industry. However, it is advisable for Sri Lankan companies to attempt engaging in international brand marketing process that enable firms to generate considerable profits and resultantly the industry becomes lucrative so that the economic benefits might reach the poor people working in the plantations.

Very few companies are doing international marketing in Sri Lanka like Dilmah, Eswaran Brother and Akbar Brothers etc. Other exporting companies too should invest to convert their exporting business into international marketing.

This study also leads to a further study measuring the international marketing orientation and marketing capabilities of firms that exports or internationally marketing Sri Lankan tea. This study based on secondary data and primary data collected from twenty six tea exporting and marketing companies. Since Sri Lanka has around two hundred tea exporters, it is required to study their needs as well to make the industry effective and efficient to a greater extent.

It is recommended that Sri Lanka needs to follow one of international entry modes that gives considerable margin in the marketing tea internationally by having international organizations created in the tea marketing companies in Sri Lanka. This will help the industry improve the profitability. It is beneficial for Sri Lanka having properly designed product, promotion, pricing and distribution strategies in accordance with the needs of international tea market are imperative for Sri Lankan tea industry to face the marketing challenges prevailing in the international tea market, which will assist Sri Lankan tea industry in competing intensively with other tea exporting or re exporting countries. Sri Lankan government may also extend massive support to the industry to convert export companies into international marketing oriented firms.

\section{References}

Ali R., Coudhry Y.A, Lister D.W. (1997), Sri Lanka's Tea Industry: Succeeding in the Global Market, World Bank Discussion Paper No. 368 .

Ariyawardana A., Bailey W.C. (2002), The Relationship between Core Resources and Strategies of Firms: The Case of Sri Lankan Value Added Tea Producers, Sri Lankan Journal of Agricultural Economics, Vol. 4, pp. 1-18.

Ariyawardeana A (2003), Sources of Competitive Advantage and Firm Performance: The Case of Sri Lankan Value-Added Tea Producers, Asia Pacific Journal of Management, Vol. 20, pp. 73-90.

Beal R.M., Lockamy A. (1999), Quality Differentiation for Competitive Advantage: A Contingency Approach, European Journal of Innovation Management, Vol. 2, No. 2, pp. 71-81.

Chaharbaghi K., Lynch L. (1999), Sustainable Competitive Advantage: Towards a Dynamic Resource-Based Strategy, Management Decision, Vol. 37, No.1, pp. 45-50.

Fonseka A.T. (1997), Strategic Approach to Marketing of Sri Lankan Tea, Sri Lankan Journal of Management, Vol. 2, No. 2, pp. 155-183.

Francis J, Colins C., Dodd (2004), Impact of Export Promotion Programs on Firm Competencies, Strategies and Performance: The case of Canadian High Technology SMEs, International Marketing Review, Vol. 21 No. 4/5, pp. 474-495.

Kanampully. J, Duddy R. (1999), Competitive Advantage Through Anticipation, Innovation and Relationships, Management Decision, Vol. 37, No. 1, pp. 51-56.

Kasturiratne D., Poole N. (2006), Creating Value for Competitive Advantage in Supply Chain 
Relationship: The Case of the Sri Lankan Tea Industry, Paper prepared for presentation at the $99^{\text {th }}$ EAAE Seminar, Germany.

Kasturiratne Dulekha (2008), An Overview of the Sri Lankan Tea Industry: An Exploratory Case Study, The Marketing Review, Vol. 8, Issue 4(Winter), pp. 367-381.

Outschoorn A.D (2000), Strategies to Enhance the Competitiveness of the Tea Industry of Sri Lanka, Sri Lankan Journal of Management, Vol. 5, No. $1 \& 2$, pp. 15-47.

Passemard D., Kleiner B.H. (2000), Competitive Advantage in Global Industries, Management Research News, Vol. 23, No. 7/8, pp. 111-117.

Pitts R.A., Lei D. (2007), Strategic Management: Building and Sustaining Competitive Advantage (4 $4^{\text {th }}$ Edition), Delhi: Thomson, South Western.

Porter, M. (1985), Competitive Advantage: Creating and Sustaining Superior Performance, The Free Press, New York, NY.

Porter, M.E (1998), The Competitive Advantage: Creating and Sustaining Superior Performance with a New Introduction, The Free Press, New York.

Poter M.E (1980), Competitive Strategy: Techniques for Analyzing Industries and Competitors, The Free Press, New York.

Prajogo D.I (2007), The Relationship Between Competitive Strategies and Product Quality, Industrial Management \& Data Systems, Vol. 107, No. 1, pp. 69-83.

Rijamampiania R., Abert R., Yumikeo (2003), A Framework for Concentric Diversification through Sustainable Advantage, Management Decision, Vol. 41, No. 4, pp. 362-371.
Rossano Eusebio, Joan Llonch Andreu and M. Pilar Lo'pez Belbeze (2007), Management Perception and Marketing Strategy in Export Performance: A Comparative Analysis in Italian and Spanish Textile-Clothing Sector, Journal of Fashion Marketing and Management, Vol. 11, No. 1, pp. 24-40.

Sri Lanka Tea Board Annual Report - 2007. 